\title{
A Comparative Study on Phenotypic Plasticity of Seven Urban Street Tree Species in Two Contrasting Environments
}

\author{
Yiyong Li ${ }^{1, *}$, Lihong Ling², Deyue Xia ${ }^{2}$, Yusheng $\mathrm{Ji}^{1}$, Jianan Wang${ }^{1}$, Chuntao Li ${ }^{1}$, \\ Yanqiong Meng ${ }^{1}$, Xiong Fang ${ }^{3}$, Yongsheng Chen ${ }^{1, * *}$ \\ ${ }^{1}$ School of Forestry and Landscape Architecture, Anhui Agricultural University, Hefei 230036, China \\ ${ }^{2}$ Anhui Province Dadi Garden Corporation, Hefei 230088, China \\ ${ }^{3}$ College of Resources and Environment, Fujian Agricultural and Forestry University, Fuzhou 350002, China
}

Received: 19 February 2020

Accepted: 19 May 2020

\begin{abstract}
The stresses imposed by impermeable paved grounds are known to result in poor health and drastically depressed benefits of street trees, but not all trees respond similarly. In this study, we investigated anatomical and chemical traits to evaluate the phenotypic plasticity of seven common street species. Analyses were performed on wood cores and leaves collected from street sites and a forest park site in Hefei, eastern China. We found significant increases in the vessel size of Sapium sebiferum (Ss) for the street trees, and the vessel frequency of Albizia julibrissin (Aj) and Koelreuteria bipinnata Franch. var. integrifoliola $(\mathrm{Kb})$, indicating higher water transport efficiency and drought resistance under impervious pavements, respectively. The specific leaf area tended to be higher in $\mathrm{Kb}$, Sapindus mukorossi ( $\mathrm{Sm}$ ) and $\mathrm{Ss}$ in the street site, while it was lower in Cinnamomum camphora (Cc) and Platanus acerifolia (Pa) for the street trees. Stomatal traits showed little change between the street site and the park site. Cc exhibited lower chlorophyll and carotenoid concentration in street trees. Ss and Cc showed high plasticity in terms of anatomical and chemical properties, respectively, while Acer buergerianum was unresponsive. These results provide a physiological basis for future street species selection in eastern China.
\end{abstract}

Keywords: roadside tree, pavement, soil sealing, water stress, anatomical plasticity, leaf nutrient

\section{Introduction}

Trees in urban areas play an irreplaceable role in supporting healthy urban communities, as they can

*e-mail: yiyonglee@ahau.edu.cn

**e-mail: chenys66@163.com ameliorate urban heat-island effect [1], reduce air pollution [2], diminish noise [3] and enhance recreational and aesthetic values [4]. However, the effectiveness of these benefits depends on growth and the health status of urban trees, which can be constrained by a range of abiotic factors including soil moisture, soil nutrients, and air quality [5]. In urban environments, trees are often surrounded by impervious pavements in streets, 
parking lots and plazas, which may be problematic for trees via increasing daytime surface temperature [6] and limiting infiltration of rainfall into the soil [7]. These paved habitats are often associated with reduced tree physiological functions, growth and survival [8-10], which eventually degrades tree ecological benefits.

Although in street tree plantings there may less limitation to growth of the canopy, the presence of prevailing impervious pavement results in limited water input and excessive water demand of street trees [11]. Water input to street trees is reduced by paved surfaces and compacted soil preventing or delaying water percolation into the root zone [12]. In addition, water demand is exacerbated because increased air temperature and decreased humidity accentuate atmospheric vapor pressure deficit, which will lead to either higher water loss or reduced carbon uptake [13]. Furthermore, heat and drought stress on urban plants could be exacerbated as the global climate continue to warm and dry [14]. Under such conditions, the growth and health status of trees depends on whether the capacity for trees to absorb and transport water could meet the requirements for water loss in transpiration. Hydraulic architectures of leaf and xylem are major determinants of water transport efficiency and can be linked to the trees' drought resistance [15]. Potential xylem hydraulic conductivity is mainly decided by the frequency and size of conduits (vessels or tracheids). In general, large conduits have higher water transport efficiency, but tend to cavitate earlier than small conduits [16]. Leaf and stomatal anatomical characteristics (e.g. stomatal size/density, vein density, the thickness of palisade and spongy mesophyll layers) that directly affect photosynthesis and water loss can also reflect plants' ability to withstand heat/drought stresses [17]. For example, by regulating stomata to be more densely packed but smaller under soil water deficits, Eucalyptus globulus can hence be able to attain higher gas diffusion through stomata [18]. High leaf vein density has also been suggested to associate with increased drought resistance, by providing alternative water flow pathways in a redundant network $[19,20]$. As key elements in tree hydraulics, xylem and leaf anatomical traits have therefore been widely investigated across various species and environments [21, 22]. However, it is not clear that how these traits response to urban impervious pavements.

Plant pigments (chlorophyll and carotenoid) are bound to harvest photosynthetic active radiation and play a functional role in protection of the photosystems [23]. Variation in pigment concentration and composition, which determines leaf color and thus decorative qualities, can be influenced by environmental factors, such as light, temperature, water and fertilization [24]. Non-structural carbohydrates (NSCs) in plants are used to lower the osmotic potential and maintain the normal turgor of cells in order to reduce harmful effects on plants [25]. Several studies found that, the NSCs increase in relatively adaptive species in response to stressful environments (e.g., low temperature, drought), while it depleted in the relatively susceptible species [26]. Environmental stress can also cause the accumulation of malondialdehyde (MDA) in plant cell membranes, which works as a marker to point out lipid peroxidation under stress conditions [27].

Previous research indicates that adjustment in the biochemical, physiological or morphological phenotype in response to changes in environmental conditions (phenotypic plasticity) can provide increased environmental tolerance/adaptability [28]. At an present, tree species in urban streets are generally selected based on aesthetic values rather than stress resistance. When chronically exposed to water deficit, heat, air and soil pollution under impervious pavements, some species may thrive with a large margin of safety based on high phenotypic plasticity, while others may operate narrowly. However, due to logistic difficulties of investigation and sampling in working urban landscapes, until recently there have been a few studies about phenotypic plasticity across various street tree species grown under land pavements. In this study, we conducted a comparative study in seven urban street tree species, as a response to an impervious paved situation versus a park situation. This work aimed to: 1) evaluate the specific phenotypic plasticity of seven commonly planted subtropical tree species to cope with impervious pavements; 2) to distinguish anatomical and chemical responses to impervious pavements.

\section{Experimental}

\section{Study Site and Tree Species}

Study sites were in the central urban area of Hefei, which is a conurbation located in the Middle East of China $\left(31^{\circ} 48^{\prime} \sim 31^{\circ} 58^{\prime} \mathrm{N}, 117^{\circ} 11^{\prime} \sim 117^{\circ} 22^{\prime} \mathrm{E}\right)$. The built-up area of this city is approximately $441 \mathrm{~km}^{2}$ (green area is $46 \%$ ), with a resident population of about 7.97 million in 2017 (Hefei Municipal Bureau of Statistics). It has a subtropical monsoon climate with cold winter and hot summer. The mean annual air temperature averages $17.1^{\circ} \mathrm{C}$, and annual precipitation totals $950 \mathrm{~mm}$. Seven tall urban street broadleaved tree species were selected in the present study due to their widespread presence in urban areas in Hefei, especially in roadsides and parks [29]. They are Acer buergerianum Miq. (Ab), Albizia julibrissin Durazz. (Aj), Cinnamomum camphora (L.) presl (Cc), Koelreuteria bipinnata Franch. var. integrifoliola (Merr.) T. Chen (Kb), Platanus $\times$ acerifolia Willd. (Pa), Sapindus mukorossi Gaertn. (Sm), Sapium sebiferum (L.) Roxb (Ss).

Seven 'street sites' were selected along streets, each of which supported one of the seven study species. In the street sites, trees were grown in belts or grids embedded in impervious pavement. A 'park site' was 
selected as a control in several open areas where the soil was covered by grass in a nearby 1003.01 hectares central city park (Hefei Dashushan National Forest Park). Experimental measurements were performed on six individuals per species at each site $(\mathrm{n}=6)$ on July 2019. All selected individuals were $>20$-yr old, with similar height and diameter for each species (Table 1).

\section{Xylem Anatomy}

In July 2019, wood cores (20-30 cm in length and $5.15 \mathrm{~mm}$ in diameter) of target trees were extracted from the stem at $1.3 \mathrm{~m}$ height by using a Haglöf CO300 increment borer (Haglöf Sweden AB, Långsele, Sweden). All wood cores were sampled from the same orientation to avoid sunshine effects. The wood core samples were then placed in a 50: 50 mixture of ethanol and water and stored at $5^{\circ} \mathrm{C}$. Transverse sections approximately 10-20 $\mu \mathrm{m}$ thick were cut using a rotary microtome (Leica RM2265, Leica Microsystems, Germany). The slice was stained with safranine, then dehydrated in a graded alcohol series, cleared with xylene and permanently fixed with Canada balsam. Images were captured of the outermost rings of xylem using a digital camera (DS-Filc, Nikon Corporation, Japan) coupled to a positive fluorescent microscope (Eclipse E200, Nikon Corporation, Japan). For each image, the following parameters were measured using a NIS Elements D software: vessel length $\left(V_{L}, \mu \mathrm{m}\right)$, vessel width $\left(V_{\mathrm{W}}, \mu \mathrm{m}\right)$, vessel perimeter $\left(V_{\mathrm{P}}, \mu \mathrm{m}\right)$, crosssectional area of vessel $\left(V_{\mathrm{A}}, \mu \mathrm{m}^{2}\right)$, vessel frequency $\left(V_{\mathrm{F}}\right.$, the number of vessels per $\left.\mathrm{mm}^{2}\right)$, and double fiber wall thickness $\left(F_{\mathrm{T}}, \mu \mathrm{m}\right)$.

\section{Leaf and Stomata Anatomy}

On a sunny morning in 15 July 2019 (10 days after rain), three to six branches were cut from the sunny portion of the canopy of each selected tree individuals. Then thirty to forty fully developed leaves were collected and kept on dry ice for later anatomical and chemical measurement. Area of five to ten leaves was determined using a portable leaf area meter (Li-3100A, $\mathrm{Li}-\mathrm{Cor}, \mathrm{USA})$, then oven dried for $48 \mathrm{~h}$ at $65^{\circ} \mathrm{C}$ to determine dry weight. For each individual, SLA was calculated as the ratio of leaf area to dry weight.

For leaf anatomy measurement, five to ten leaves were fixed in formalin-acetic acid-alcohol (FAA) solution for at least $24 \mathrm{~h}$. Transverse thin sections were obtained by a Leica RM2265 rotary microtome, stained with safranin and fast green dye, and photographed under proper magnification by a Nikon Eclipse E200 microscope to measure leaf thickness $\left(L_{\mathrm{T}}\right)$, upper and lower epidermis thickness $\left(U E_{\mathrm{T}}\right.$ and $\left.L E_{\mathrm{T}}\right)$, palisade tissue thickness $\left(P_{\mathrm{T}}\right)$ and spongy tissue thickness $\left(S_{\mathrm{T}}\right)$. For vein density $\left(V_{\mathrm{D}}\right)$, leaf samples were bleached with $5 \%$ sodium hydroxide until the veins were exposed, then were rinsed in distilled water and stained with $1 \%$ safranine solution, and photographed under a Nikon Eclipse E200 microscope. Vein length per leaf area was measured using ImageJ (http://rsb.info.nih.gov/ij/).

To measure stomata anatomy, leaf epidermises on the adaxial side were taken centrally in the leaf midway. Mounted sections were observed using a Nikon Eclipse E200 light microscope. For each epidermal peel, 20 stomata were sampled to measure stomatal length $\left(S_{\mathrm{L}}\right)$ and width $\left(S_{\mathrm{W}}\right)$ and 3 fields $(300 \mu \mathrm{m} \times 300 \mu \mathrm{m})$ were sampled for stomatal density $\left(S_{\mathrm{D}}\right)$.

Table 1. Characteristics of species and sites in the present study. DBH: diameter at breast height (means \pm SE).

\begin{tabular}{|c|c|c|c|c|c|}
\hline Species & Code & Site & $\mathrm{DBH}(\mathrm{cm})$ & Grid size $(\mathrm{cm})$ & Pavement material \\
\hline \multirow{2}{*}{ Acer buergerianum } & $\mathrm{Ab}$ & Park & $23.9 \pm 0.8$ & & \\
\hline & & Street & $19.2 \pm 1.0$ & $65 \times 65$ & Concrete \\
\hline \multirow{2}{*}{ Albizia julibrissin } & $\mathrm{Aj}$ & Park & $28.5 \pm 2.6$ & & \\
\hline & & Street & $21.8 \pm 0.6$ & Strips of $45 \mathrm{~cm}$ width & asphalt \\
\hline \multirow{2}{*}{ Cinnamomum camphora } & $\mathrm{Cc}$ & Park & $30.8 \pm 2.0$ & & \\
\hline & & Street & $27.4 \pm 1.1$ & $130 \times 130$ & asphalt \\
\hline \multirow{2}{*}{ Koelreuteria bipinnata. var. integrifoliola } & $\mathrm{Kb}$ & Park & $22.1 \pm 1.5$ & & \\
\hline & & Street & $28.3 \pm 1.2$ & $30 \times 30 \mathrm{~cm}$ & Concrete \\
\hline \multirow{2}{*}{ Platanus $\times$ acerifolia } & $\mathrm{Pa}$ & Park & $48.6 \pm 2.7$ & & \\
\hline & & Street & $32.7 \pm 0.8$ & $130 \times 130$ & asphalt \\
\hline \multirow{2}{*}{ Sapindus mukorossi } & $\mathrm{Sm}$ & Park & $18.7 \pm 1.1$ & & \\
\hline & & Street & $21.6 \pm 0.3$ & $80 \times 80$ & asphalt \\
\hline \multirow{2}{*}{ Sapium sebiferum } & Ss & Park & $28.0 \pm 2.1$ & & \\
\hline & & Street & $28.8 \pm 2.2$ & $100 \times 100$ & Concrete \\
\hline
\end{tabular}




\section{Leaf Chemical Analyses}

Oven-dried leaf samples were ground to fine powder in a ball mill to determine soluble sugar $(S s)$ and starch $(S t)$ concentration. Ss was extracted using an ethanol technique and determined using the anthrone colorimetric assay [30]. St was determined using a total starch assay kit (Megazyme International Ireland Ltd, Wicklow, Ireland). Non-structural carbohydrates (NSCs) concentration was calculated as the sum of $S \mathrm{~s}$ and $S \mathrm{t}$.

Photosynthetic pigments were extracted using $10 \mathrm{ml}$ of $80 \%$ acetone from $0.1 \mathrm{~g}$ fresh leaf samples and centrifuged at $4000 \mathrm{~g}$ for $5 \mathrm{~min}$. The supernatant's absorbance levels were detected at 663, 646 and $470 \mathrm{~nm}$. The contents of chlorophyll a (Chl a), chlorophyll b (Chl b), carotenoid (Car) and total pigment content (Pigs) were calculated according to [31].
For the measurement of malondialdehyde (MDA) content, $0.5 \mathrm{~g}$ fresh leaf materials was homogenized with $1.5 \mathrm{~mL} 5 \%$ trichloroacetic acid $(\mathrm{w} / \mathrm{v})$, then centrifuged at $3000 \mathrm{rpm}$ for $10 \mathrm{~min} .2 \mathrm{~mL}$ of supernatant were added to $2 \mathrm{~mL}$ of $0.6 \%$ thiobarbituric acid in $5 \%$ trichloroacetic acid, then kept in water bath for $20 \mathrm{~min}$, and centrifuged at $3000 \mathrm{rpm}$ for $10 \mathrm{~min}$. The aqueous phases were then measured at 450,532, and $600 \mathrm{~nm}$, respectively. MDA contents were calculated according to $[32]$.

\section{Statistical Analysis}

The site effect and its interaction with species on all parameters were analysed by two-way ANOVA. Intraspecific traits between the street site and the park site were compared by independent samples $t$-tests. Principal component analyses (PCA) were conducted

Table 2. Significance (p-values) of terms from two-way ANOVA analysis for the effects of site, species and their interactions on anatomical and chemical traits.

\begin{tabular}{|c|c|c|c|c|}
\hline Parameter & Code & Site & Species & Site $\times$ Species \\
\hline Vessel frequency & $V_{\mathrm{F}}$ & 0.024 & $<0.001$ & 0.003 \\
\hline Vessel area & $V_{\mathrm{A}}$ & 0.035 & $<0.001$ & ns \\
\hline Vessel width & $V_{\mathrm{W}}$ & 0.037 & $<0.001$ & ns \\
\hline Vessel length & $V_{\mathrm{L}}$ & 0.020 & $<0.001$ & ns \\
\hline Vessel perimeter & $V_{\mathrm{P}}$ & 0.025 & $<0.001$ & ns \\
\hline Double Fiber wall thickness & $F_{\mathrm{T}}$ & 0.022 & $<0.001$ & ns \\
\hline Specific leaf area & SLA & ns & $<0.001$ & $<0.001$ \\
\hline Leaf vein density & $V_{\mathrm{D}}$ & $<0.001$ & $<0.001$ & 0.001 \\
\hline Leaf thickness & $L_{\mathrm{T}}$ & ns & $<0.001$ & ns \\
\hline Upper epidermis thickness & $U E_{\mathrm{T}}$ & ns & $<0.001$ & 0.004 \\
\hline Lower epidermis thickness & $L E_{\mathrm{T}}$ & ns & $<0.001$ & ns \\
\hline Palisade tissue thickness & $P_{\mathrm{T}}$ & ns & $<0.001$ & ns \\
\hline Spongy tissue thickness & $S_{\mathrm{T}}$ & 0.017 & $<0.001$ & ns \\
\hline Stomatal length & $S_{\mathrm{L}}$ & ns & $<0.001$ & ns \\
\hline Stomatal width & $S_{\mathrm{W}}$ & ns & $<0.001$ & 0.043 \\
\hline Stomatal density & $S_{\mathrm{D}}$ & ns & $<0.001$ & ns \\
\hline Stomatal pore area index & SPI & ns & 0.005 & ns \\
\hline Leaf soluble sugar & $S \mathrm{~s}$ & 0.001 & $<0.001$ & 0.022 \\
\hline Leaf starch & $S \mathrm{t}$ & 0.009 & $<0.001$ & 0.001 \\
\hline Leaf nonstructural carbohydrates & $N S C \mathrm{~s}$ & $<0.001$ & $<0.001$ & 0.001 \\
\hline Malondialdehyde & MDA & ns & $<0.001$ & ns \\
\hline Chlorophyll a & Chl a & ns & $<0.001$ & 0.002 \\
\hline Chlorophyll b & $\mathrm{Chl} \mathrm{b}$ & ns & $<0.001$ & 0.001 \\
\hline Carotenoid & Car & ns & $<0.001$ & 0.004 \\
\hline Pigments & Pigs & ns & $<0.001$ & 0.001 \\
\hline
\end{tabular}


on the wood anatomical traits, leaf anatomical traits, stomatal traits and leaf chemical traits, respectively. For each variable, we determine phenotypic plasticity index (PPI) based on the following expression: PPI $=$ (species mean 1 - species mean 2)/(the larger species mean) [33]. All analyses were performed using R v.3.5.0 (R Development Core team, 2018).

\section{Results and Discussion}

\section{Wood Anatomical Traits}

As shown in Table 2, site and species significantly influenced wood anatomical traits, but there was no significant interaction between sites and species for all wood anatomical traits except for vessel frequency $\left(V_{\mathrm{F}}\right)$ (Table 2). Sapium sebiferum (Ss) increased vessel area $\left(V_{\mathrm{A}}\right)$, vessel length $\left(V_{\mathrm{L}}\right)$, vessel width $\left(V_{\mathrm{w}}\right)$ and vessel perimeter $\left(V_{\mathrm{P}}\right)$, and increased fiber cell wall thickness $\left(F_{\mathrm{T}}\right)$ in the street site compared with the park site (Fig. 1). Platanus acerifolia (Pa) decreased $V_{\mathrm{w}}$ in the street site. $V_{\mathrm{F}}$ of Koelreuteria bipinnata. var. integrifoliola $(\mathrm{Kb})$ significant increases in street trees. In contrast, Sapindus mukorossi $(\mathrm{Sm})$ decreased $V_{\mathrm{F}}$ in the street site. In Albizia julibrissin (Aj) and Cinnamomum camphora $(\mathrm{Cc})$, all wood anatomical traits did not differ significantly between sites.
Wood anatomical traits were respectively subjected to principal component analysis (PCA) according to sites and species (Fig. 5a). The first principal component (PC1) accounted for $83 \%$ and the second component (PC2) for $12 \%$ of the variation in the dataset. The wood anatomical traits of $\mathrm{Cc}$ at the street site were significantly separated from those at the park site on both PC1 and PC2 axis $(p<0.01)$. We also found significant difference of $\mathrm{Kb}$ between the sites on $\mathrm{PC} 2$ axis $(p<0.05)$.

\section{Leaf Anatomical Traits}

Specific leaf area (SLA) was significantly higher at the street sites than the park site in $\mathrm{Kb}, \mathrm{Sm}$ and $\mathrm{Ss}$ (Fig. 2). In contrast, in $\mathrm{Cc}$ and $\mathrm{Pa}$, SLA significantly decreased in street trees. Vein density $\left(V_{\mathrm{D}}\right)$ in $\mathrm{Aj}, \mathrm{Cc}$, $\mathrm{Kb}$ and $\mathrm{Ss}$ significantly increased at the street site compared with the park site. Upper epidermis thickness $\left(U E_{\mathrm{T}}\right)$ in $\mathrm{Cc}, \mathrm{Ss}$, and lower epidermis thickness $\left(L E_{\mathrm{T}}\right)$ in $\mathrm{Kb}$ showed significantly decrease in street trees. For leaf thickness $\left(L_{\mathrm{T}}\right)$, palisade tissue thickness $\left(P_{\mathrm{T}}\right)$ and spongy tissue thickness $\left(S_{\mathrm{T}}\right)$, there was no significant difference between sites in all species. According to PCA (Fig. 5b), we found significant differences of leaf anatomical traits between the street site and the park site in Ss $(p<0.05$ on $\mathrm{PC} 1$ axis; $p<0.01$ on PC2 axis), $\mathrm{Cc}(p<0.05$ on $\mathrm{PC} 2$ axis $)$ and $\mathrm{Kb}(p<0.01$ on $\mathrm{PC} 2$ axis $)$.

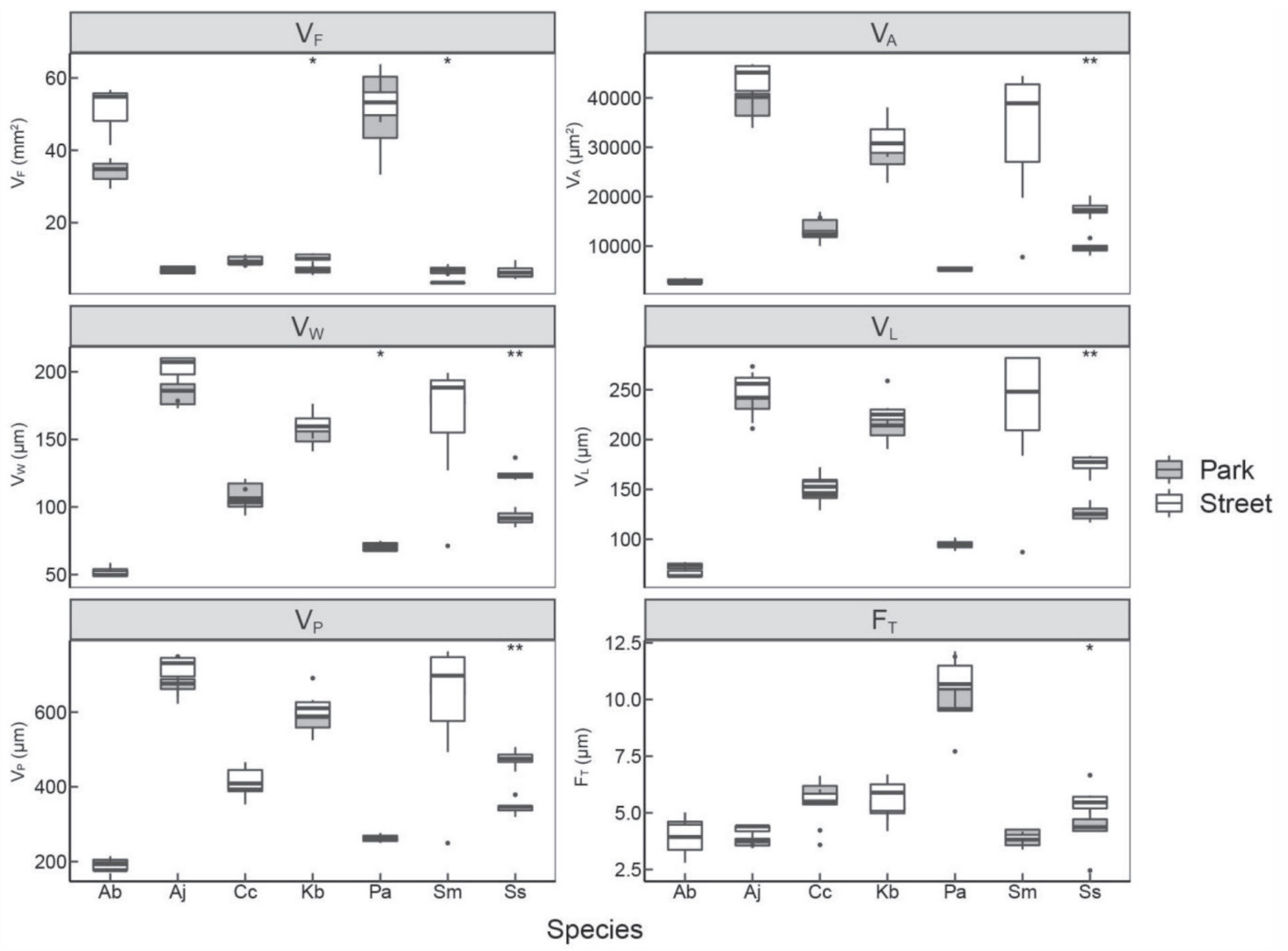

Fig. 1. Box-plots of wood anatomical properties for seven species at a park site (gray boxes) and street sites (white boxes). See Table 1 for species codes. * and ** at the top of each box denote significant differences between the two sites for a species at $\mathrm{p}<0.05$ and $\mathrm{p}<0.01$, respectively. 

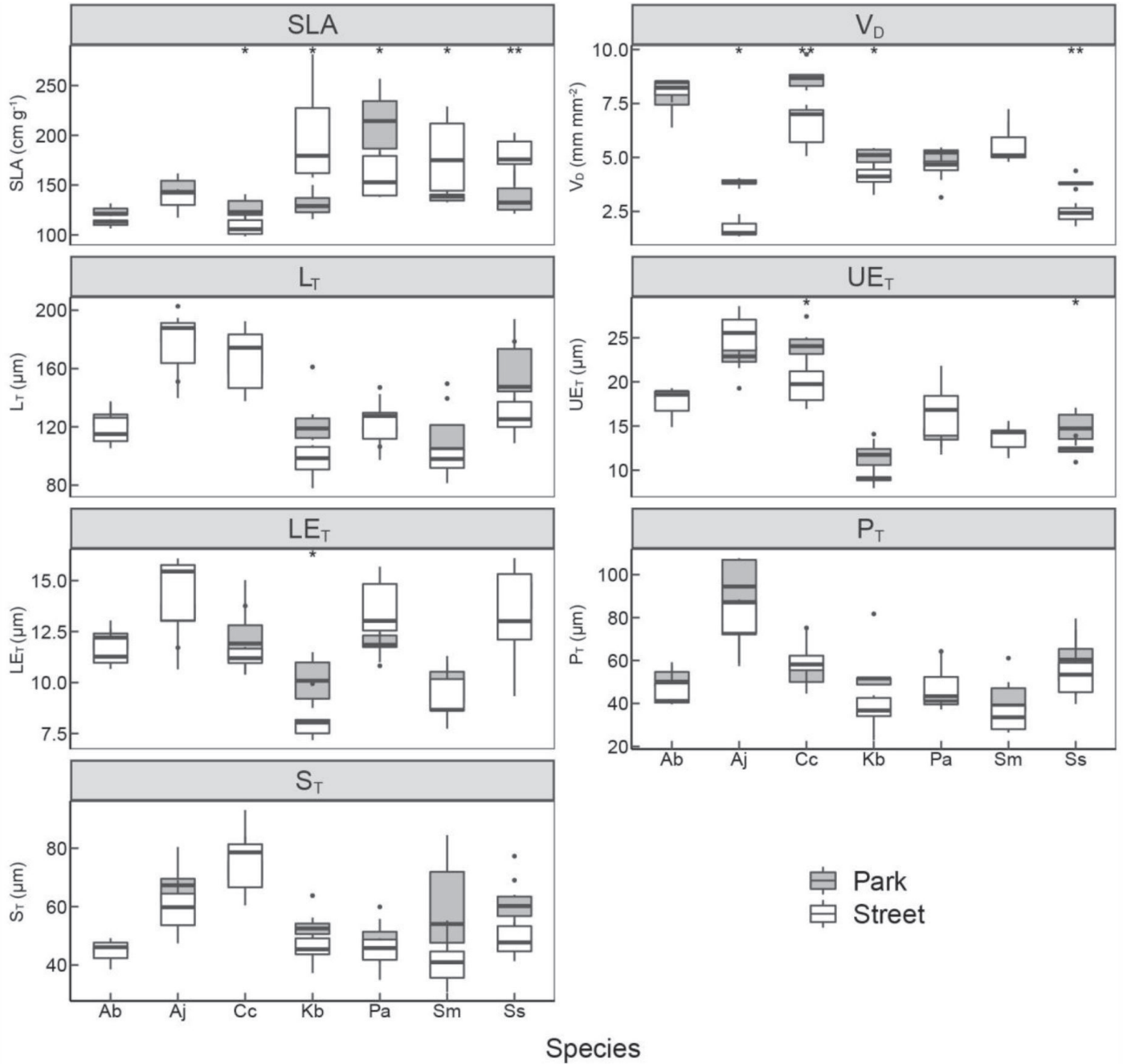

Park

Street

Fig. 2. Box-plots of leaf anatomical properties for seven species at a park site (gray boxes) and street sites (white boxes). See Table 1 for species codes. * and ** at the top of each box denote significant differences between the two sites for a species at $\mathrm{p}<0.05$ and $\mathrm{p}<0.01$, respectively.

\section{Stomatal Anatomical Traits}

Stomatal length $\left(S_{\mathrm{L}}\right)$ and stomatal density $\left(S_{\mathrm{D}}\right)$ did not vary significantly between the street site and the park site in all species (Fig. 3). Stomatal width $\left(S_{\mathrm{w}}\right)$ showed significantly increase in street trees of $\mathrm{Aj}$. In $\mathrm{Cc}$ and $\mathrm{Pa}$, stomatal pore index (SPI) significantly increased in the street sites. Based on the results of PCA (Fig. 5c), there was only significant difference of stomatal anatomical traits between the two sites in $\mathrm{Cc}$ $(p<0.05$ on $\mathrm{PC} 2$ axis).

\section{Leaf Chemical Traits}

Leaf soluble sugar content (Ss) was significantly higher at the street sites than at the park site in Cc and $\mathrm{Kb}$ (Fig. 4). Leaf starch content (St) significantly increased in the street site in $\mathrm{Cc}$ and $\mathrm{Aj}$, but decreased in $\mathrm{Pa}$. In all species, non-structural carbohydrates (NSCs) tended to be higher in the street sites than in the park site, but the differences were only statistically significant in Cc. At the street site, the chlorophyll-a content (Chl a), chlorophyll-b content $(\mathrm{Chl} b)$, carotenoid content (Car) and total pigment content (Pigs) in $\mathrm{Cc}$ were significantly lower than those at the park site. In Aj, Pigs also showed significantly decrease in street trees, while other species showed no significantly change between the sites. There was no significant difference of malondialdehyde (MDA) between the sites in all species. According to PCA (Fig. 5d), the leaf chemical traits of $\mathrm{Cc}$ at the street site were significantly separated from those at the park site on both PC1 and PC2 axis $(p<0.01)$. We also found significant difference of $\mathrm{Aj}$ between the sites on $\mathrm{PC} 2$ axis $(p<0.01)$.

\section{Plasticity of Anatomical and Chemical Traits}

These seven tree species exhibited different anatomical and chemical plastic responses between the park site and the street site (Fig. 6). The mean PPI 


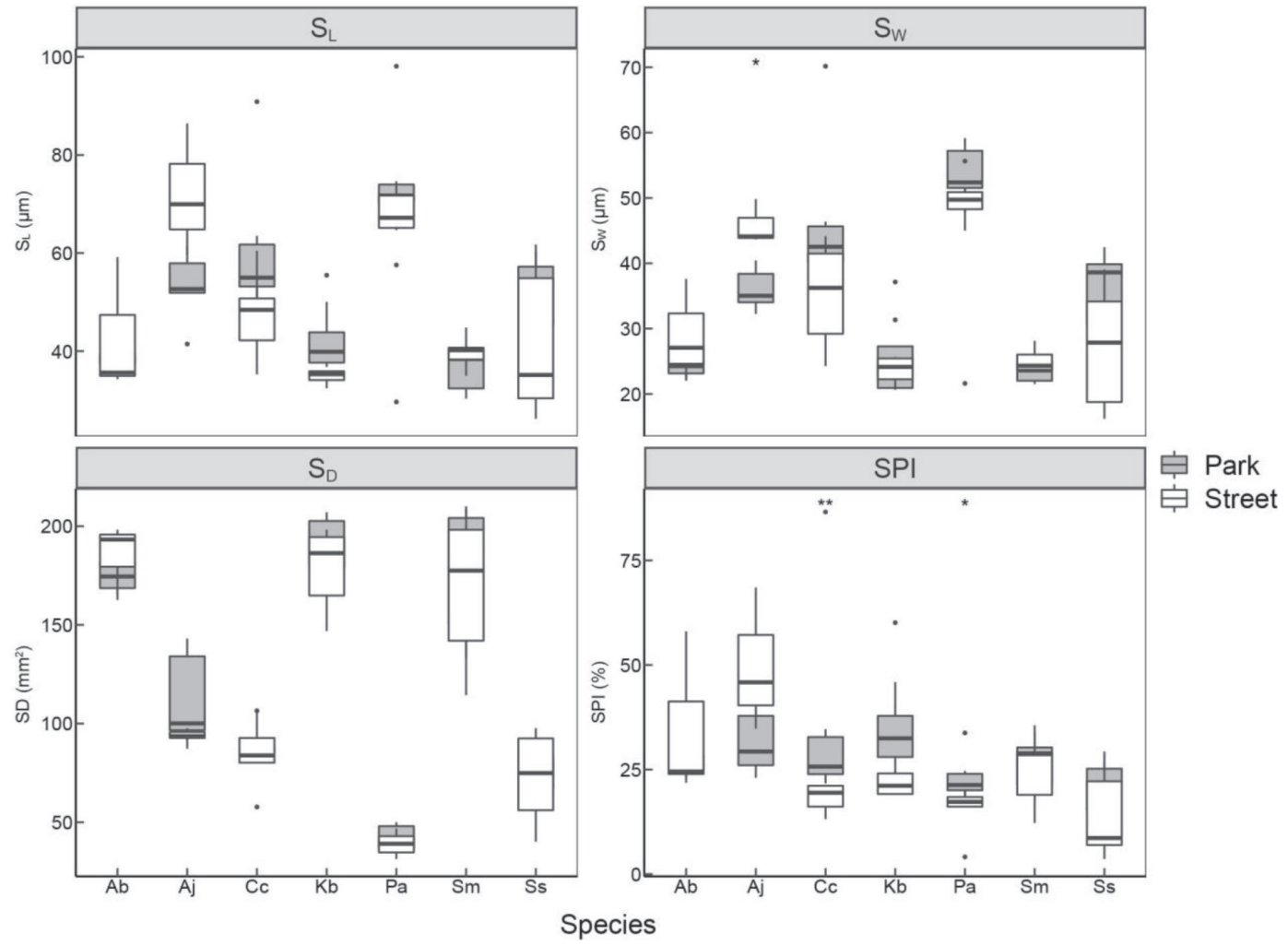

Fig. 3. Box-plots of stomatal anatomical properties for seven species at a park site (gray boxes) and street sites (white boxes). See Table 1 for species codes. * and ** at the top of each box denote significant differences between the two sites for a species at $\mathrm{p}<0.05$ and $\mathrm{p}<0.01$, respectively.

values of chemical features were higher than those of anatomical features. Ss and Cc showed high plasticity in terms of anatomical and chemical properties, respectively.

Our study provides evidence that land pavement along roadside significantly influenced wood anatomy, leaf anatomy, stomatal anatomy and leaf chemistry of trees grown at the street sites in comparison to the park site. We also observed marked differences in phenotypic plasticity of anatomical and chemical traits across the seven street tree species, even though they had been grown in the same conditions in a long-term.

Recent pioneer studies have concluded that impervious pavement alters water relations of urban trees by analyzing plant hydraulic conductivity $[10$, $34,35]$. However, few studies have focused on the corresponding effects of hydraulic infrastructure on the water transport efficiency under land pavement. In our study, we found inter-specific differences in wood anatomy of the study species. Among the seven species, Sapium sebiferum (Ss, Chinese tallow tree), which is native to eastern Asia and known to be invasive elsewhere, showed the highest phenotypic plasticity in wood anatomy, in terms of increased vessel size in newly formed xylem. This result was consistent to previous studies that, as an invasive species, Ss can tolerate wide environmental variation and obtain an advantage in changing environments, which would contribute to invasion success [36, 37]. Larger vessels will result in increases in xylem hydraulic conductivity [38]. Although we did not measure it in this study, we could expect that Ss grown at the street site are able to transport water more efficiently and to better support tree growth [39-41]. A reverse pattern was observed in Platanus acerifolia $(\mathrm{Pa})$, where vessel width $\left(V_{\mathrm{w}}\right)$ were found to be smaller at the street site, suggesting more restriction in water transport. Platanus spp., which is widely planted as street trees, has been reported to be higher water use compared to other urban tree species in Los Angeles [42]. According to previous studies, it was generally thought that there was a tradeoff between the hydraulic efficiency associated with larger vessels and their vulnerability to cavitation $[16,43]$. In our study, Ss grown under pavements appears to improve the hydraulic conductivity, rather than the vulnerability to cavitation. In addition, we found significantly increase of vessel frequency $\left(V_{\mathrm{F}}\right)$ in Koelreuteria bipinnata. var. integrifoliola $(\mathrm{Kb})$ at the street site. The increased $V_{\mathrm{F}}$ can ensure some vessels remain active while others might be affected by cavitation [44], indicating xylem hydraulic adaptation of $\mathrm{Kb}$ to minimize drought induced cavitation risk and to avoid hydraulic failure under land pavement [45].

A leaf with a large area per unit mass (specific leaf area, SLA) could imply a higher potential for photosynthesis and growth; in contrast, a low SLA is better able to store water and associated with adaptability to high water stress [46, 47]. In 

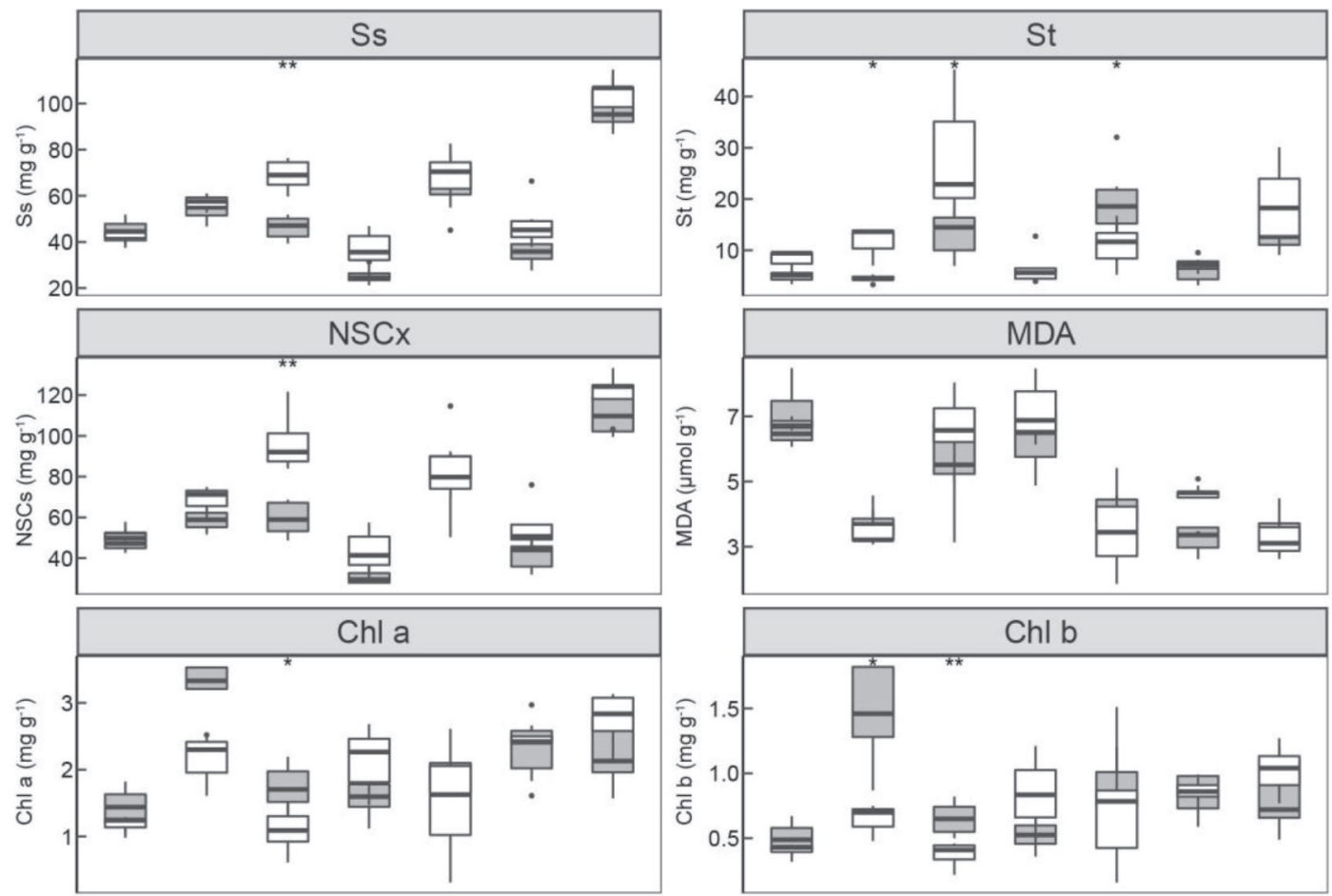

Park

官 Street
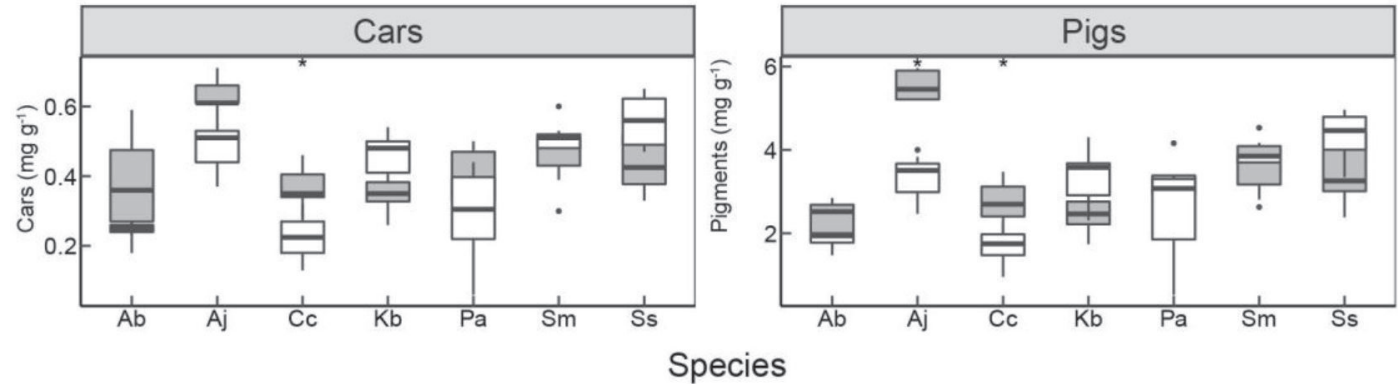

Fig. 4. Box-plots of leaf chemical properties for seven species at a park site (gray boxes) and street sites (white boxes). See Table 1 for species codes. $*$ and $* *$ at the top of each box denote significant differences between the two sites for a species at $\mathrm{p}<0.05$ and $\mathrm{p}<0.01$, respectively.

our study, Kb, Sapindus mukorossi (Sm) and $\mathrm{Ss}$ tended to have higher SLA in the street site, while Cinnamomum camphora $(\mathrm{Cc})$ and $\mathrm{Pa}$ decreased SLA in street trees, indicating different strategies under land pavement. In addition, we found higher vein density $\left(V_{\mathrm{D}}\right)$ of Albizia julibrissin (Aj), $\mathrm{Cc}, \mathrm{Kb}$ and $\mathrm{Ss}$ in the street site compared with the park site. Similar results can be found in drought resistant plants which, when grown with reduced rainfall, exhibit increased $V_{\mathrm{D}}$ together with water use efficiency, since $V_{\mathrm{D}}$ has been associated with leaf hydraulic conductance, photosynthesis within and across species [48-50]. The increased $V_{\mathrm{D}}$ could result from declining leaf width or increasing vein numbers in response to altered vapor pressure deficit (VPD) [51,52]. Increased epidermal thickness is considered to be an efficient mechanism for water conservation which might decrease leaf transpiration resulting in a higher water use efficiency [53]. However, the epidermis of our studied species did not present this characteristic under pavement. In contrast, $\mathrm{Cc}$ and $\mathrm{Ss}$ in the street site had thinner upper and lower epidermal tissue $\left(U E_{\mathrm{T}}\right.$ and
$L E_{\mathrm{T}}$ ), which could benefit gas exchanges and improve $\mathrm{CO}_{2}$ distribution from the stomata throughout tree leaves [54]. There was limited variation of palisade and spongy tissue thickness between the sites for all species.

In this study, $\mathrm{Cc}$ in the street site displayed higher leaf soluble sugar $(S \mathrm{~s})$, starch $(S \mathrm{t})$ and non-structural carbohydrate concentrations (NSCs) than those in the park site (Fig. 4). Increased NSCs probably is likely to indicate that the gross photosynthetic activity fully meets or exceeds the demand for carbon in growth and respiration [55]. It may result from enhanced photosynthesis due to the higher air temperature at the street site. However, we did not photosynthesis in the present study. If drought persists, then source limitation will occur and NSCs will decrease or will become inaccessible through mobilization and/or phloem failure before death. Malondialdehyde (MDA) concentration, which has been considered an indicator of oxidative damage to leaf structure and function, has been shown to be correlated with the stress of temperature/water to plants [56, 57]. Compared with the park site, MDA did 

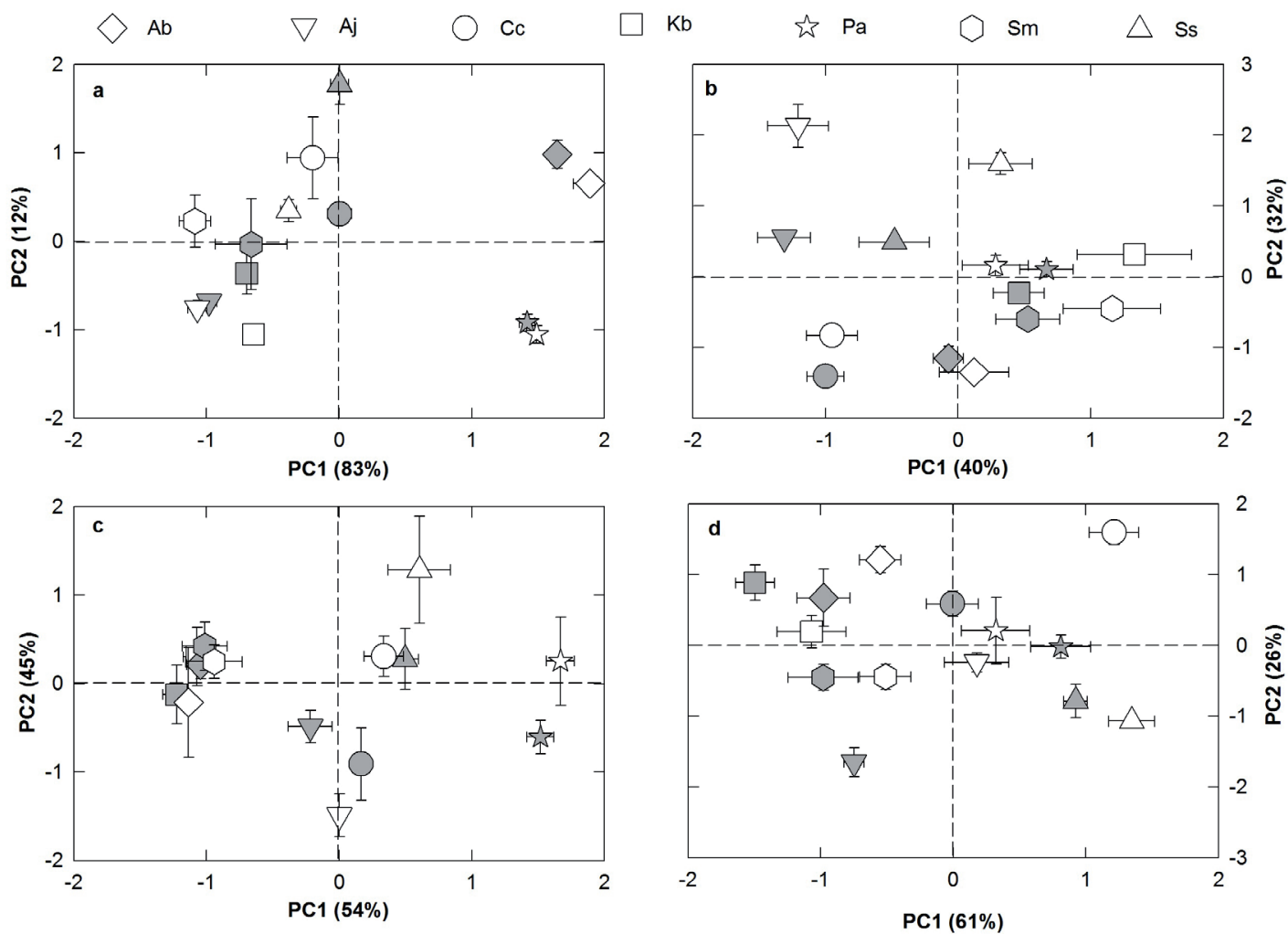

Fig. 5. Principal component analysis for a) 6 wood anatomical traits, b) 7 leaf anatomical traits, c) 4 stomatal traits and d) 8 leaf chemical traits for seven species at a park site (gray) and street sites (white). Different symbols indicate the seven tree species: Pa (five-pointed star), Ss (triangle), Ab (diamond), Cc (circle), Sm (hexagon), Aj (inverted triangle) and Kb (square). See Table 1 for species codes.

not change significantly at the street sites for all species. This result indicates that serious plasma membrane lipid peroxidation of the studied species may not happen under the drought/heat stress caused by land pavement in the street site [58].

In the present study, Cc exhibited lower chlorophyll a (Chl a), chlorophyll b (Chl b), carotenoid (Car) and

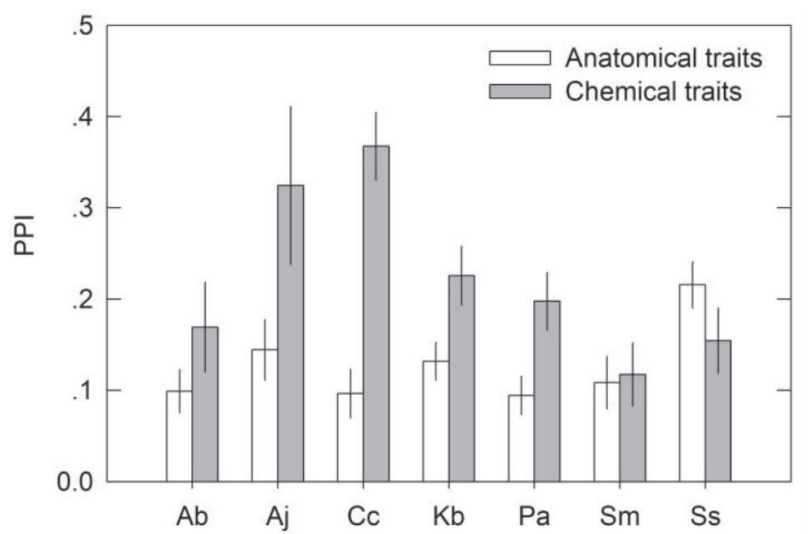

Fig. 6. Index of phenotypic plasticity (PPI) in response to pavements for 17 anatomical traits (white bars) and 8 chemical traits (grey bars) in seven urban tree species. Data are means \pm SE. See Table 1 for species codes. pigments (Pigs) concentration in the street site compared to the park site. Numerous studies have shown that drought and/or heat can decrease photosynthetic pigment content due to reduction of chlorophyll synthesis and inhibition of photosynthetic enzymes [59]. In addition, it may also result from decreased soil nutrient availability such as $\mathrm{Mg}$ and $\mathrm{P}$, or the root uptake of nutrients [60] in paved soils. Reduced photosynthetic pigments can directly limit its photosynthetic potential and hence primary production. For the other species, we did not observe any significant change, indicating that photosynthetic pigment of $\mathrm{Cc}$ is more sensitive to impervious pavements.

Acers, which are commonly cultivated in urban areas across the temperate world due to its ornamental value, are generally thought to be moderately drought tolerant [61]. In our study, among the seven studies species, Acer buergerianum (Ab, trident maple) was the only species showed no significant change in all anatomical and chemical variables, exhibiting low phenotypic plasticity. However, Ab displayed the smallest xylem vessel size among the seven species, indicating the ability to avoid cavitation and decline in function. 


\section{Conclusions}

Land pavements in urban area are challenging environments for street trees. Our data indicates that land pavement could change the xylem structure, leaf structure and chemistry of the street species in urban area. Our findings suggested that the responses of anatomical and chemical traits to land pavement were species specific. Among species, street trees of Sapium sebiferum, Albizia julibrissin and Koelreuteria bipinnata var. integrifoliola appeared to increase vessel size and frequency. Stomatal traits showed little change between the street site and the park site. Cinnamomum camphora showed lower chlorophyll and carotenoid concentration, and higher leaf non-structural carbohydrates concentration in street trees. The study provides practical information for tree management in urban sites, but also suggests that key plant processes and responses such as xylem vessel size, non-structural carbohydrates and specific leaf area are fundamental for a full understanding of responses of urban trees to environmental stresses. However, data must be interpreted with caution, as several other confounding variables (eg., air/soil pollution) that might affect the physiology of urban trees were not explicitly investigated in this study. Further studies are still needed to explore the dependence of pavement on other soil and plant traits.

\section{Acknowledgements}

This research was funded by the National Natural Science Foundation of China (31800511) and the Fund of Anhui Province Dadi Garden Corporation (kj20180218). We thank Lili Peng, Huihui Liu, Cheng Zhang, Chenfei Liang, Min Yu, Mengyu Zhou for assistance in data collection.

\section{Conflict of Interest}

The authors declare no conflict of interest.

\section{References}

1. WANG Y., AKBARI H. The effects of street tree planting on Urban Heat Island mitigation in Montreal. Sustainable Cities and Society. 27, 122, 2016.

2. JANHäLL S. Review on urban vegetation and particle air pollution - Deposition and dispersion. Atmospheric Environment. 105, 130, 2015.

3. PATHAK V., TRIPATHI B.D., MISHRA V.K. Evaluation of anticipated performance index of some tree species for green belt development to mitigate traffic generated noise. Urban Forestry \& Urban Greening. 10, 61, 2011.

4. BOLUND P., HUNHAMMAR S. Ecosystem services in urban areas. Ecological Economics. 29, 293, 1999.
5. SJÖMAN H., BUSSE NIELSEN A. Selecting trees for urban paved sites in Scandinavia - A review of information on stress tolerance and its relation to the requirements of tree planners. Urban Forestry \& Urban Greening. 9, 281, 2010.

6. HERB W.R., JANKE B., MOHSENI O., STEFAN H.G. Ground surface temperature simulation for different land covers. Journal of Hydrology. 356, 327, 2008.

7. JIANG Y., FU P., WENG Q. Assessing the impacts of urbanization-associated land use/cover change on land surface temperature and surface moisture: A case study in the Midwestern United States. Remote Sensing. 7, 4880, 2015.

8. WANG X.-M., WANG X.-K., SU Y.-B., ZHANG H.-X. Land pavement depresses photosynthesis in urban trees especially under drought stress. Science of The Total Environment. 653, 120, 2019.

9. DE LA MOTA DANIEL F.J., DAY S.D., OWEN J.S., STEWART R.D., STEELE M.K., SRIDHAR V. Porouspermeable pavements promote growth and establishment and modify root depth distribution of Platanus $\times$ acerifolia (Aiton) Willd. in simulated urban tree pits. Urban Forestry \& Urban Greening. 33, 27, 2018.

10. FINI A., FRANGI P., MORI J., DONZELLI D., FERRINI F. Nature based solutions to mitigate soil sealing in urban areas: Results from a 4-year study comparing permeable, porous, and impermeable pavements. Environmental Research. 156, 443, 2017.

11. WHITLOW T.H., BASSUK N.L., REICHERT D.L. A 3 -Year study of water relations of urban street trees. Journal of Applied Ecology. 29, 436, 1992.

12. MORGENROTH J., BUCHAN G., SCHARENBROCH B.C. Belowground effects of porous pavements-Soil moisture and chemical properties. Ecological Engineering. 51, 221, 2013.

13. MCDOWELL N., POCKMAN W.T., ALLEN C.D., BRESHEARS D.D., COBB N., KOLB T., PLAUT J., SPERRY J., WEST A., WILLIAMS D.G., YEPEZ E.A. Mechanisms of plant survival and mortality during drought: why do some plants survive while others succumb to drought? New Phytologist. 178, 719, 2008.

14. OLESON K.W., MONAGHAN A., WILHELMI O., BARLAGE M., BRUNSELL N., FEDDEMA J., HU L., STEINHOFF D.F. Interactions between urbanization, heat stress, and climate change. Climatic Change. 129, 525, 2015.

15. LENS F., SPERRY J.S., CHRISTMAN M.A., CHOAT B., RABAEY D., JANSEN S. Testing hypotheses that link wood anatomy to cavitation resistance and hydraulic conductivity in the genus Acer. New Phytologist. 190, 709, 2011.

16. CAI J., TYREE M.T. The impact of vessel size on vulnerability curves: data and models for within-species variability in saplings of aspen, Populus tremuloides Michx. Plant, Cell \& Environment. 33, 1059, 2010.

17. LAMAOUI M., JEMO M., DATLA R., BEKKAOUI F. Heat and drought stresses in crops and approaches for their mitigation. Frontiers in Chemistry. 6, 2018.

18. FRANKS P.J., DRAKE P.L., BEERLING D.J. Plasticity in maximum stomatal conductance constrained by negative correlation between stomatal size and density: an analysis using Eucalyptus globulus. Plant, Cell \& Environment. 32, 1737, 2009.

19. SCHNEIDER J.V., HABERSETZER J., RABENSTEIN R., WESENBERG J., WESCHE K., ZIZKA G. Water supply and demand remain coordinated during breakdown 
of the global scaling relationship between leaf size and major vein density. New Phytologist. 214, 473, 2017.

20. NARDINI A., PEDÀ G., LA R.N. Trade-offs between leaf hydraulic capacity and drought vulnerability: morpho-anatomical bases, carbon costs and ecological consequences. New Phytologist. 196, 788, 2012.

21. KIORAPOSTOLOU N., PETIT G. Similarities and differences in the balances between leaf, xylem and phloem structures in Fraxinus ornus along an environmental gradient. Tree Physiology. 39, 234, 2018.

22. LÜBBE T., SCHULDT B., LEUSCHNER C. Acclimation of leaf water status and stem hydraulics to drought and tree neighbourhood: alternative strategies among the saplings of five temperate deciduous tree species. Tree Physiology. 37, 456, 2016.

23. BARICKMAN T.C., KOPSELL D.A. Nitrogen form and ratio impact Swiss chard (Beta vulgaris subsp. cicla) shoot tissue carotenoid and chlorophyll concentrations. Scientia Horticulturae. 204, 99, 2016.

24. HAN Q., LUO J., LI Z., KORPELAINEN H., LI C. Improved drought resistance by intergeneric graftingin Salicaceae plants under water deficits. Environmental and Experimental Botany. 155, 217, 2018.

25. DIETZE M.C., SALA A., CARBONE M.S., CZIMCZIK C.I., MANTOOTH J.A., RICHARDSON A.D., VARGAS R. Nonstructural carbon in woody plants. Annual review of plant biology. 65, 667, 2014.

26. PIPER F.I. Drought induces opposite changes in the concentration of non-structural carbohydrates of two evergreen Nothofagus species of differential drought resistance. Annals of Forest Science. 68, 415, 2011.

27. HUSSAIN S., KHAN F., CAO W., WU L., GENG M. Seed priming alters the production and detoxification of reactive oxygen intermediates in rice seedlings grown under suboptimal temperature and nutrient supply. Frontiers in Plant Science. 7, 2016.

28. CHEVIN L.-M., LANDE R., MACE G.M. Adaptation, plasticity, and extinction in a changing environment: Towards a predictive theory. PLOS Biology. 8, e1000357, 2010.

29. LI Y.Y., WANG X.R., HUANG C.L. Key street tree species selection in urban areas. African Journal of Agricultural Research. 6, 3539-3550, 2011.

30. EBELL L.F. Variation in total soluble sugars of conifer tissues with method of analysis. Phytochemistry. 8, 227, 1969.

31. WELLBURN A.R. The spectral determination of chlorophylls a and $\mathrm{b}$, as well as total carotenoids, using various solvents with spectrophotometers of different resolution. Journal of Plant Physiology. 144, 307, 1994.

32. FAZELI F., GHORBANLI M., NIKNAM V. Effect of drought on biomass, protein content, lipid peroxidation and antioxidant enzymes in two sesame cultivars. Biologia Plantarum. 51, 98, 2007.

33. VALLADARES F., SANCHEZ-GOMEZ D., ZAVALA M.A. Quantitative estimation of phenotypic plasticity: bridging the gap between the evolutionary concept and its ecological applications. Journal of Ecology. 94, 1103, 2006.

34. SAVI T., BERTUZZI S., BRANCA S., TRETIACH M., NARDINI A. Drought-induced xylem cavitation and hydraulic deterioration: risk factors for urban trees under climate change? New Phytologist. 205, 1106, 2015.

35. OSONE Y., KAWARASAKI S., ISHIDA A., KIKUCHI S., SHIMIZU A., YAZAKI K., AIKAWA S.-I., YAMAGUCHI M., IZUTA T., MATSUMOTO G.I. Responses of gas-exchange rates and water relations to annual fluctuations of weather in three species of urban street trees. Tree Physiology. 34, 1056, 2014.

36. CHEN L., TIU C.J., PENG S., SIEMANN E. Conspecific plasticity and invasion: invasive populations of Chinese tallow (Triadica sebifera) have performance advantage over native populations only in low soil salinity. PLoS One. 8, e74961-e74961, 2013.

37. DENG B., LIU X., ZHENG L., LIU Q., GUO X., ZHANG L. Effects of nitrogen deposition and UV-B radiation on seedling performance of Chinese tallow tree (Triadica sebifera): A photosynthesis perspective. Forest Ecology and Management. 433, 453, 2019.

38. MCELRONE A.J., POCKMAN W.T., MARTíNEZVILALTA J., JACKSON R.B. Variation in xylem structure and function in stems and roots of trees to $20 \mathrm{~m}$ depth. New Phytologist. 163, 507, 2004.

39. COCHARD H., TYREE M.T. Xylem dysfunction in Quercus: vessel sizes, tyloses, cavitation and seasonal changes in embolism. Tree Physiology. 6, 393, 1990.

40. LOVISOLO C., SCHUBERT A. Effects of water stress on vessel size and xylem hydraulic conductivity in Vitis vinifera L. Journal of Experimental Botany. 49, 693, 1998.

41. HAWORTH M., CENTRITTO M., GIOVANNELLI A., MARINO G., PROIETTI N., CAPITANI D., DE CARLO A., LORETO F. Xylem morphology determines the drought response of two Arundo donax ecotypes from contrasting habitats. Global Change Biology Bioenergy. 9, 119, 2017.

42. PATAKI D.E., MCCARTHY H.R., LITVAK E., PINCETL S. Transpiration of urban forests in the Los Angeles metropolitan area. Ecological Applications. 21, 661, 2011.

43. HARGRAVE K.R., KOLB K.J., EWERS F.W., DAVIS S.D. Conduit diameter and drought-induced embolism in Salvia mellifera Greene (Labiatae). New Phytologist. 126, 695, 1994.

44. VENTURAS M.D., SPERRY J.S., HACKE U.G. Plant xylem hydraulics: What we understand, current research, and future challenges. Journal of Integrative Plant Biology. 59, 356, 2017.

45. HACKE U.G., STILLER V., SPERRY J.S., PITTERMANN J., MCCULLOH K.A. Cavitation fatigue. Embolism and refilling cycles can weaken the cavitation resistance of xylem. Plant Physiology. 125, 779, 2001.

46. BUSSOTTI F., POLLASTRINI M., HOLLAND V., BRüGGEMANN W. Functional traits and adaptive capacity of European forests to climate change. Environmental and Experimental Botany. 111, 91, 2015.

47. GREENWOOD S., RUIZ-BENITO P., MARTÍNEZVILALTA J., LLORET F., KITZBERGER T., ALLEN C.D., FENSHAM R., LAUGHLIN D.C., KATTGE J., BöNISCH G., et al. Tree mortality across biomes is promoted by drought intensity, lower wood density and higher specific leaf area. Ecology Letters. 20, 539, 2017.

48. SAVI T., LOVE V.L., DAL BORGO A., MARTELLOS S., NARDINI A. Morpho-anatomical and physiological traits in saplings of drought-tolerant Mediterranean woody species. Trees. 31, 1137, 2017.

49. LEI Z.Y., HAN J.M., YI X.P., ZHANG W.F., ZHANG Y.L. Coordinated variation between veins and stomata in cotton and its relationship with water-use efficiency under drought stress. Photosynthetica. 56, 1326, 2018.

50. SCOFFONI C., RAWLS M., MCKOWN A., COCHARD H., SACK L. Decline of leaf hydraulic conductance with dehydration: Relationship to leaf size and venation architecture. Plant Physiology. 156, 832, 2011.

51. WANG X., DU T., HUANG J., PENG S., XIONG D. Leaf 
hydraulic vulnerability triggers the decline in stomatal and mesophyll conductance during drought in rice. Journal of Experimental Botany. 69, 4033, 2018.

52. CARINS MURPHY M.R., JORDAN G.J., BRODRIBB T.J. Acclimation to humidity modifies the link between leaf size and the density of veins and stomata. Plant, Cell \& Environment. 37, 124, 2014.

53. KRöBER W., HEKLAU H., BRUELHEIDE H. Leaf morphology of 40 evergreen and deciduous broadleaved subtropical tree species and relationships to functional ecophysiological traits. Plant Biology. 17, 373, 2015.

54. VERBOVEN P., HERREMANS E., HELFEN L., HO Q.T., ABERA M., BAUMBACH T., WEVERS M., NICOLAï B.M. Synchrotron X-ray computed laminography of the three-dimensional anatomy of tomato leaves. The Plant Journal. 81, 169, 2015.

55. KöRNER C. Carbon limitation in trees. Journal of ecology. 91, 4, 2003.

56. FAROOQ M., WAHID A., LEE D.J., CHEEMA S.A., AZIZ T. Comparative time course action of the foliar applied glycinebetaine, salicylic acid, nitrous oxide, brassinosteroids and spermine in improving drought resistance of rice. Journal of Agronomy and Crop Science. 196, 336, 2010.
57. JIN B., WANG L., WANG J., JIANG K.-Z., WANG Y., JIANG X.-X., NI C.-Y., WANG Y.-L., TENG N.-J. The effect of experimental warming on leaf functional traits, leaf structure and leaf biochemistry in Arabidopsis thaliana. BMC Plant Biology. 11, 35, 2011.

58. MARNETT L.J. Lipid peroxidation - DNA damage by malondialdehyde. Mutation Research/Fundamental and Molecular Mechanisms of Mutagenesis. 424, 83, 1999.

59. MUNNÉ-BOSCH S., ALEGRE L. Die and let live: leaf senescence contributes to plant survival under drought stress. Functional Plant Biology. 31, 203, 2004.

60. LIN J., WANG Y., SUN S., MU C., YAN X. Effects of arbuscular mycorrhizal fungi on the growth, photosynthesis and photosynthetic pigments of Leymus chinensis seedlings under salt-alkali stress and nitrogen deposition. Science of The Total Environment. 576, 234, 2017.

61. SJöMAN H., HIRONS A.D., BASSUK N.L. Urban forest resilience through tree selection - Variation in drought tolerance in Acer. Urban Forestry \& Urban Greening. 14, 858, 2015. 